\title{
METHODOLOGICAL BASES AND PRINCIPLES OF FORMATION OF THE ORGANIZATIONAL STRUCTURE OF THE ENTERPRISE BY THE GOLDEN RATIO THEORY
}

\author{
Alla Opalenko', Oksana Rudenko²
}

\begin{abstract}
The relevance of the study of business process management at manufacturing enterprises is determined by the presence of uncertainty and the existence of risks, in particular, structural risks. The timeliness and value of the abovementioned problem are also determined by the low level of implementation of risk management at enterprises. The provision of mechanisms for increasing the level of risk management is an extremely relevant problem of the modern economy, and the construction of risk optimization models is one of the main in the system of factors that affect the effective operation of the enterprise and the prospects for its development. The purpose of the article is to determine principles of formation and approaches to the construction of an "ideal" organizational structure of a manufacturing enterprise. The application of such principles will allow conducting effective management of a production enterprise. Methodology. Development of economic systems requires from industrial enterprises to develop new approaches to business process management, contributes to the spread of innovation in all spheres of production, forms a new image of structures, and provides their competitiveness in the domestic and world markets. An important area of research is the management of business processes of the enterprise, which will provide conditions for the development and effective operation of production enterprises on the basis of new knowledge, technologies, and effective management. The study was carried out based on the activity of PJSC "Shpolyansky Foodstuffs Plant" for 2014-2018. The practical result of the research conducted is recommendations for the implementation of the risk management system at the manufacturing enterprise, and as a stage - building an "ideal" organizational structure that will allow timely responding to the problems of risk management. Originality. Enterprises combine many business processes that carry out thousands of operations, therefore, it is relevant to develop effective approaches suitable for their detailed description, analysis of the features of operation, optimization, control, diagnosis of problem situations, and the formation of measures for their elimination, management of structural risks. This requires the creation of effective tools for solving these tasks.
\end{abstract}

Key words: business process, economic system, risk management, organizational model of risk management system, organizational structure of enterprise, harmonization (golden ratio principle), structural risk.

JEL Classification: B40, D20, L20

\section{Introduction}

A significant contribution to the development of theoretical and applied provisions in the field of studying the peculiarities of the operation and analysis of business processes of enterprises is made by a lot of domestic and foreign scientists, among which it is worth to highlight the works written by I. Alieksieiev (Alieksieiev, 2016), P. Bazylevych (Bazylevych, 2011), A. Vendrov (Vendrov, 2004), O. Korzachenko (Korzachenko, 2015), L. Vylkov, J. Becker, M. Kugeler, V. Taratukhyn (Becker, Vylkov, Kugeler, Taratukhyn,

\footnotetext{
Corresponding author:

${ }^{1}$ Cherkasy State Technological University, Ukraine.

E-mail: seyalla@ukr.net

ORCID: https://orcid.org/0000-0001-8783-2149

${ }^{2}$ Cherkasy State Technological University, Ukraine.

E-mail: ksyxarudenko@gmail.com

ORCID: https://orcid.org/0000-0002-0713-5405
}

Rosemann, 2007), V. Repin (Repin, 2013), and many others. In their works, scholars focus on the study of the essence of the description of features of the operation of enterprises and individual business processes, their structuring and restructuring, analysis, the main advantages and disadvantages of existing approaches, etc.

Business process modelling is a way to make the production enterprise more efficient, to get the description of the process through various elements, to structure the issues. So, one of the directions - is the 
study of the organizational structure of the enterprise as a way to model business processes.

Many scholars studied the concept of "organizational structure". So, the papers by I. Ihnatieva (Ihnatieva, 2008), N. Kaliuzhna (Kaliuzhna, 2005), N. Metelenko (Metelenko, 2009), S. Petrenko (Petrenko, 2010), I. Prodius (Prodius, 2012), K. Simakov (Simakov, 2001), and I. Sedikova (Sedikova, 2013) conduct a comparison of the types of organizational structures, present advantages and disadvantages, concepts of development, formation, specify principles and stages of improvement of organizational structures of management. The conducted studies allow stating that there is currently no single, universal organizational structure of management of a production enterprise.

Thus, the relevant scientific and applied task is to develop an organizational model of the risk management system of a production enterprise, taking into account the specificity of activities in order to ensure effective operation in an unstable environment.

Organizational model (enterprise model) in the context of defining the concept of business modelling is defined in the work by M. Fox (Fox, 1998) as a representation or presentation of a structure, activity, processes, information, resources, people, goals, and constraints on organization of business, government or other form of organization.

The organizational model of the risk management system of a production enterprise shows the interdependence and interconnection of all elements of the structure, and also reveals their main functional responsibilities. In particular, the paper by I. Pysarevskyi (Pysarevskyi, 2008) notes that organizational structure regulates the division of tasks between subdivisions, their competence in solving certain problems, the general interaction of these elements.
When constructing the organizational model of the risk management system, it is necessary to specify the structure of subordination of units, to define functions, powers, and responsibilities.

\section{Multilayer management system in accordance with the system approach principle}

The management system according to the system approach principle, which is proposed in the paper by V. Volkova (Volkova, 2001), includes layers of decision-making (choice, training and adaptation, selforganization). Scholars propose to form multilayer decision-making systems for solving business management problems (Figure 1).

In works by O. Markovskyi (Markovskyi, 2010), this multilayer structure was developed, taking into account the current state of activities of Ukrainian banks, and another accounting and control block was included. The analysis conducted showed that for production enterprises, the separation of the accounting and control block is also relevant. From the point of view of the general principles, in Fig. 2, a multilayer organizational model of the enterprise structure was constructed using a modified multilayer structure by O. Markovskyi (Markovskyi, 2010).

The activity of a production enterprise is associated with the emergence of risk under the influence of various factors of the unstable external (internal) environment. Thus, for example, refusal or untimely delivery of raw materials (materials) will stop the technical process of production, so a risk of loss of regular consumers of manufactured products appears. Another example is the change in the raw material price or the growth in the size of loan commitments or lease payments for the use of industrial equipment, premises, land plots, or the lack of temporarily free funds for investment, which also leads to risk and lower the enterprise performance.

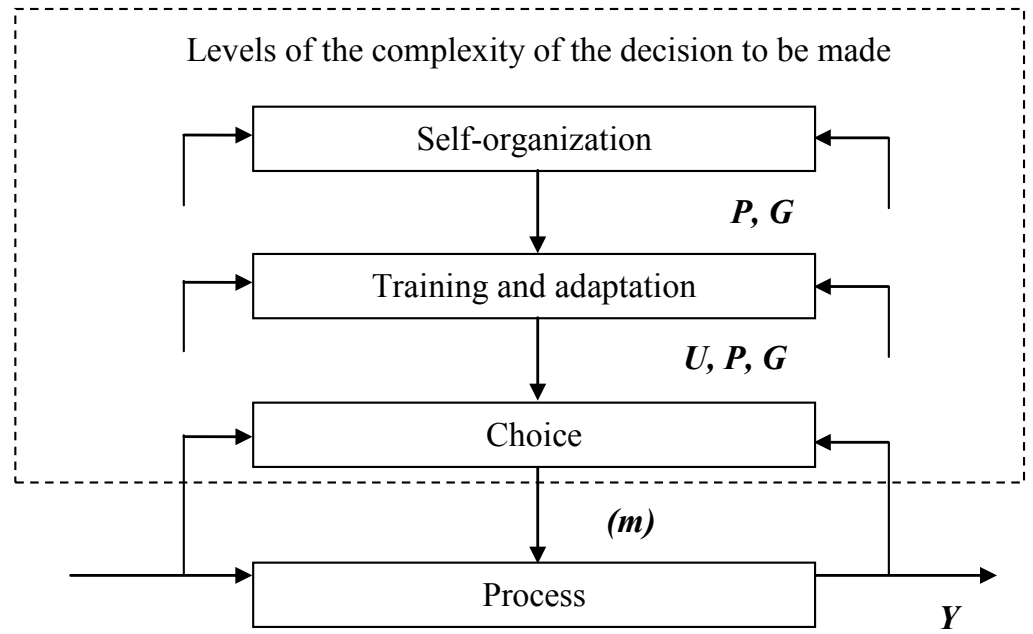

Figure 1. The multilayer structure of decision-making

Source: Volkova, 2001 


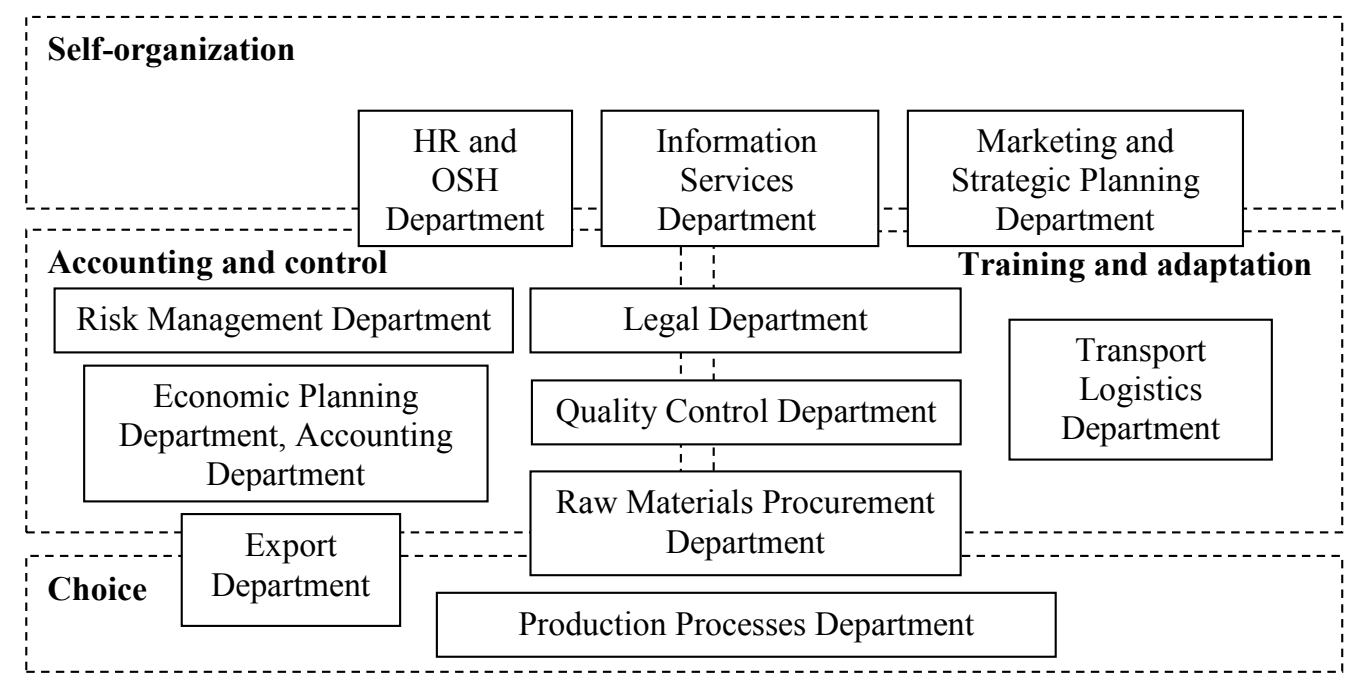

Figure 2. Multilayer organizational model of enterprise structure

Source: compiled by the author based on (Markovskyi, 2010; Harashchuk, 2009)

\section{Key aspects for building a harmonious organizational structure of the enterprise}

Let us consider more in detail the issue of harmonization and the "golden ratio". The principle of the golden ratio is used in various fields of activity. Among researchers, it is necessary to distinguish O. Ivanus (Ivanus, 2003, 2005, $2006,2008,2011)$, who, in particular, in the monograph (Ivanus, 2011) describes modern stages of development and study of the concept of harmony by scholars, formulates problems of innovative economics and the need for its harmonization, theoretical approaches and methodological basis of the concept of innovation management as a harmonious management, i.e. which is based on the golden ratio principles; describes the automated system of harmonious innovation management. In the paper (Ivanus, Myronova, 2008), O. Ivanus and N. Myronova have concluded that firms and industries that are successfully developing in accordance with a certain set goal of maximizing profits, in their development tend to self-harmonization of their indicators. The reason for this is that the maximization of the global system indicator leads to an increase in the number of indicators and parameters of the system, which are distributed according to the normal law (Gauss's law). I. Kriuchkova (Kriuchkova, 2004, 2008), O. Bilotserkivets, T. Burlai, N. Honchar (Bilotserkivets, Burlai, Honchar, 2007), studying this problem, came to the conclusion that economic dynamics depend on proportions, the principle of the golden ratio in the economy contributes to the optimization of the "energy" of growth, and not by the principle of "growth for accumulation" but growth for a stable social progress. I. Kriuchkova (Kriuchkova, 2004, 2008) emphasizes that the harmony for European countries is closer to the golden ratio, and for Ukraine, taking into account that it is in the phase of economic recovery, the structure differs from the harmonious one because there are violations in the macrostructural proportions of GDP, namely, in the distribution of primary and gross income between sectors of the economy, which led to a violation of the proportion that determines the stability of development - between consumer spending and capital formation. This, according to the scholar, is the reason for the reduction of investment in the sphere of production. In the monograph, N. Hronska (Hronska, 2006) considers the principles, methodological aspects, and models of harmonious transformations of the spheres of the economy and management, proposes marketing, logistics, environmental concepts of harmonious transformations. The scholar describes the process of formation of a paradigm of harmonious transformations in relations between economic and ecological environments. I. Dezhkina (Dezhkina, 2008) uses the principle of the golden ratio in the management of an industrial enterprise; V. Vyshnevetskyi, H. Hryshuk, and V. Vyshnevetskyi (Vyshnevetskyi, 2006) underline the importance of the golden ratio for the development of small and mediumsized business. S. Ivanchuk (Ivanchuk, 2008) connects the principle of the golden ratio with the lifecycle of economic systems. Among the scholars who also investigated the golden ratio, the processes of self-organization and selfdevelopment of systems, E. Soroko (Soroko, 2003, 2006) and M. Radiuk (Radiuk, 2003) can be highlighted.

For business process modelling, in particular, the construction of an ideal organizational structure of a production enterprise, the research of activities of PJSC "Shpolyansky Foodstuffs Plant" was conducted, the activity of which is aimed at the production of cacao, chocolate, and sugar confectionery. Figure 3 presents the organizational structure of Shpolyansky Foodstuffs Plant PJSC (until 2014) and Figure 4 - the organizational structure of Shpolyansky Foodstuffs Plant PJSC approved on September 1, 2014. 


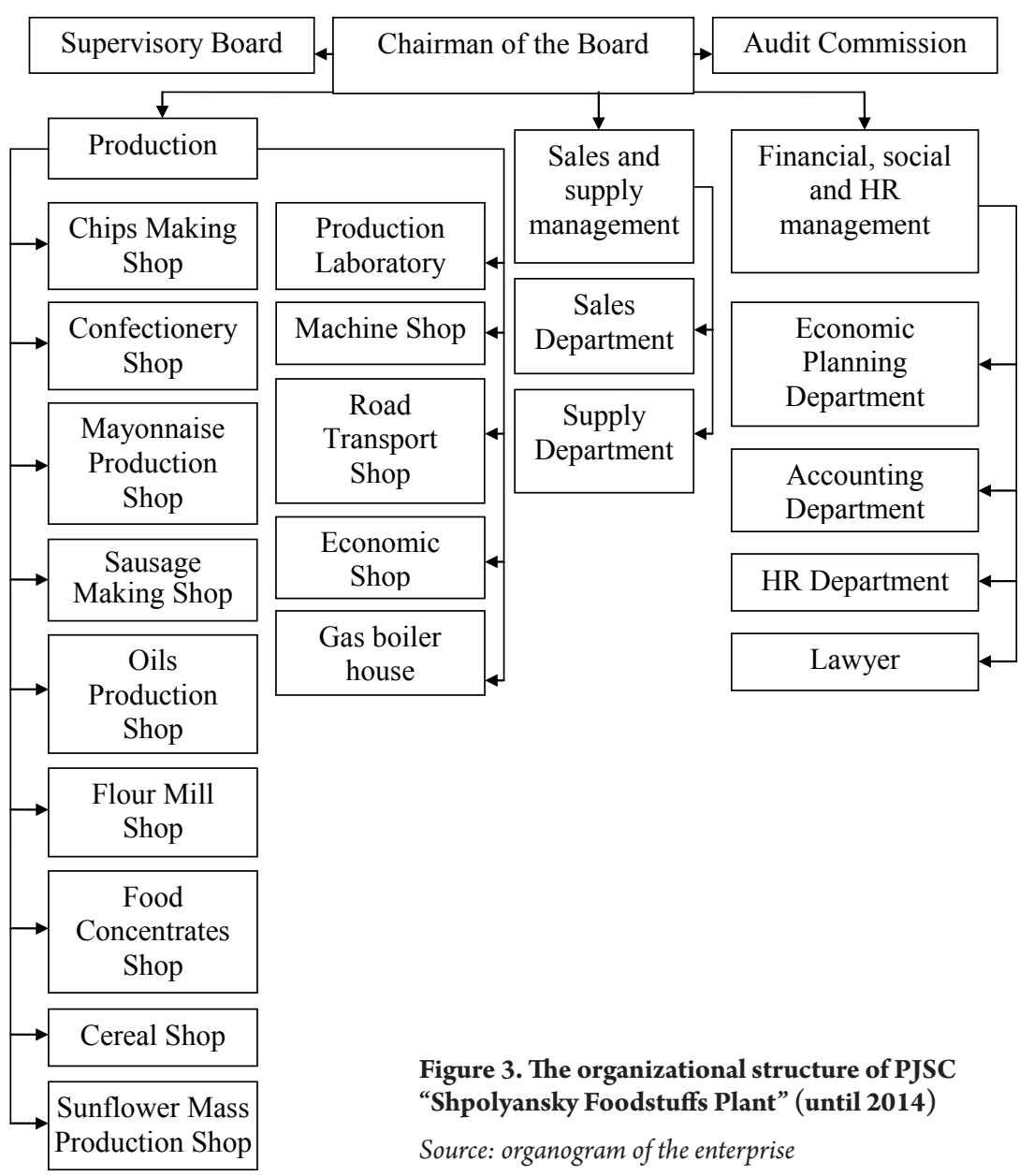

Thus, for the introduction of the risk management system at a production enterprise, it is necessary to create a separate structural unit - the Risk Management Department. It should be noted that the development of job descriptions of employees, the formation of an effective system of division of powers among employees, the establishment of communication channels and the transmission of information - an integral part of the implementation and effective operation of the department. Separated and included in the accounting and audit block, the Risk Management Department ensures timely detection, analysis, and management of risks of the enterprise. An obligatory condition for decision-making is to take into account the time aspect (Figure 5), that is, the dependence of the level of uncertainty in the enterprise's activity on time.

An enterprise is a complex economic system that unites interdependent components of productioneconomic, technological, and external environment. It is the complexity of economic processes and uncertainty that emphasize the need for the Risk Management Department to timely respond to changes in the external environment. Fig. 6 represents a scheme of managerial influence on enterprise activity.

The risks that arise in the course of the enterprise activity are investigated, recorded, analysed, quantitatively and qualitatively evaluated, and an action plan for managing them is developed. The management of the enterprise approves managerial decisions regarding the implementation of measures to reduce the level of risks (negative consequences) to favourable for the enterprise, as well as partial elimination or reduction of risk factors. As a result, we have a managerial influence that changes the activity of the enterprise.

Having added the organizational structure with the Risk Management Department, it is also worth analysing on what layer it will be located. The Department controls core activities of the enterprise, that is, it should be in the block of accounting and control. The complexity of the external environment is determined by a number of factors, which affect the enterprise activity and, consequently, the Risk Management Department. It is the employees of this department who must study, research, analyse, quantitatively and qualitatively evaluate, reduce the negative impact of risks on the activities of the production enterprise.

The organizational model has a clear structure, functions, and place of the Risk Management Department in the overall management system of a production enterprise, and if the costs for the activity of each stratum are consistent with the principle of harmony, then it is considered to be an "ideal" organizational structure. 


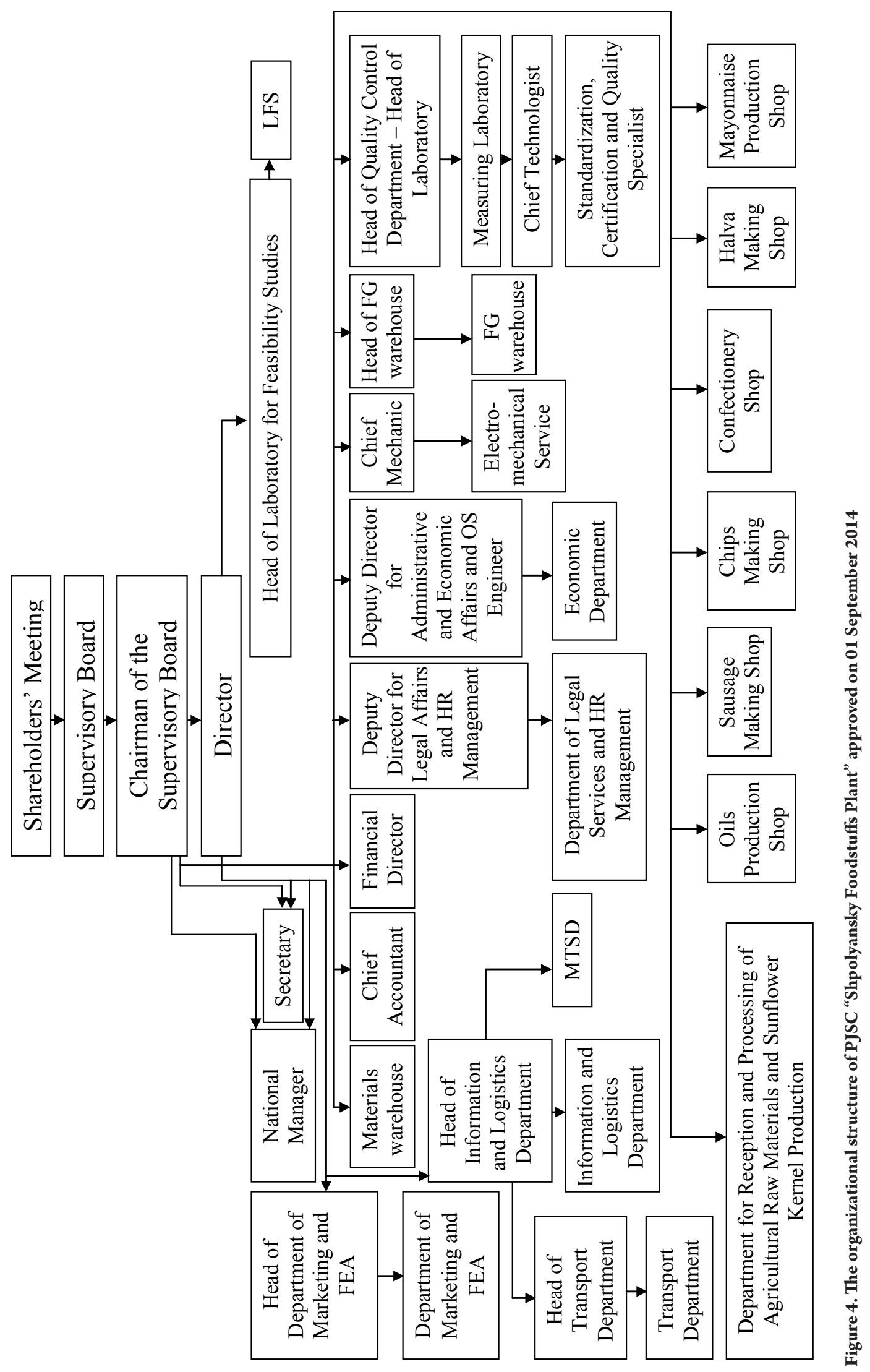


Vol. 5, No. 2, 2019

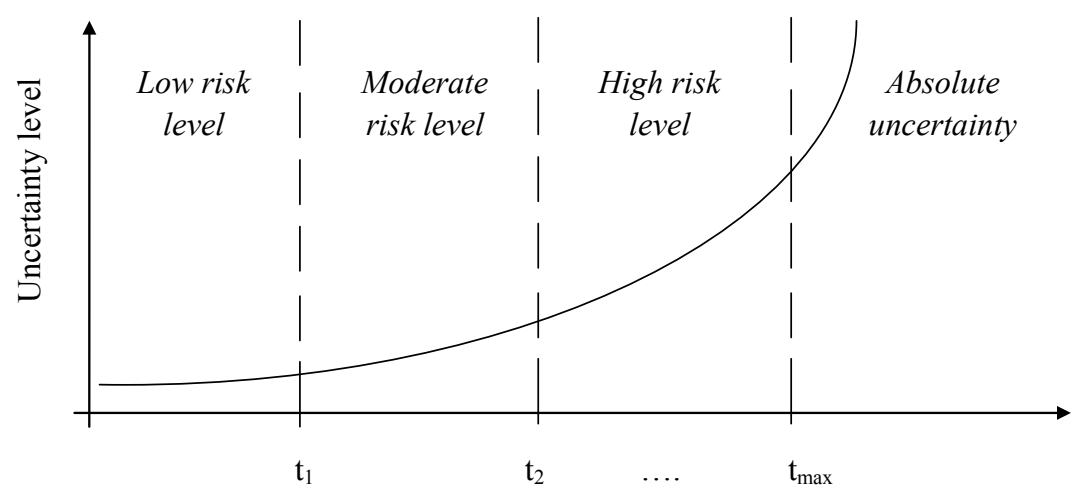

Figure 5. Time dependence of uncertainty level in the activity of the system

Source: developed by the author

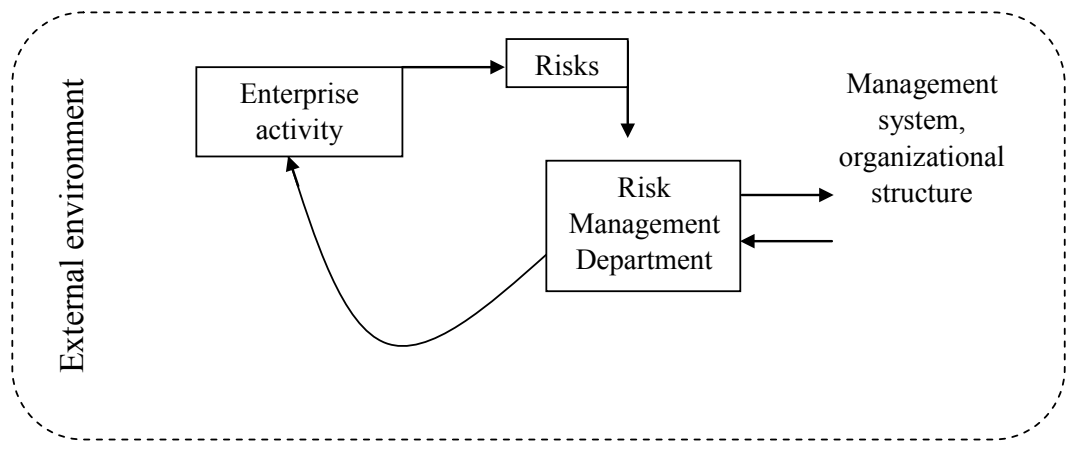

Figure 6. Scheme of managerial influence on enterprise activity

Source: supplemented on the basis of (Klymenko, 2011)

\section{Research results}

The main principles of the formation of an "ideal" organizational structure are presented in Table 1.
According to the above table, there are three approaches to building an "ideal" organizational structure, namely: regarding the production enterprise,

Table 1

Principles of forming an "ideal" organizational structure of a production enterprise

\begin{tabular}{|l|l|}
\hline \multirow{5}{*}{$\begin{array}{l}\text { Regarding the production } \\
\text { enterprise itself }\end{array}$} & The orientation of management structure to achieve long-term operating results \\
\cline { 2 - 3 } & Structural-functional ordering, which manifests itself in close relations between structural elements \\
\hline & Effective solving of management tasks in the operating organizational structure \\
\hline & The flow of information should not be meaningfully distorted \\
\hline & Close links between goals, objectives, economic conditions \\
\hline & Efficient use of available resources \\
\hline \multirow{5}{*}{$\begin{array}{l}\text { Effective staffing, training, sufficient incentives, a professional and psychological adaptation of human resources } \\
\text { management }\end{array}$} & Enterprise reorganization should address the causes of conflict situations and solve problems in general \\
\hline Improvement of production activity of the enterprise \\
\hline & Improvement of the quality of managerial decisions \\
\hline & The management's authorities to make managerial decisions should be focused on long-term strategies \\
\hline & $\begin{array}{l}\text { As in large and complex systems, the chief executive (director general) cannot directly monitor all processes, it } \\
\text { is worthwhile to group the units at the top management level }\end{array}$ \\
\hline & Transparency in structural subdivisions and high professional skills of heads of these subdivisions \\
\hline & A small number of deputy directors, whose duties and responsibilities are clearly delineated \\
\hline & $\begin{array}{l}\text { The presence of change management specialists, whose tasks are to ensure the enterprise's response to changing } \\
\text { market conditions }\end{array}$ \\
\hline & $\begin{array}{l}\text { Small time expenditure of the enterprise management to eliminate situations that arise as a result of mismatch } \\
\text { of the organizational structure used }\end{array}$ \\
\hline No misuse of powers \\
\hline
\end{tabular}




\begin{tabular}{|l|l|}
\hline \multirow{5}{*}{$\begin{array}{l}\text { Regarding the Risk } \\
\text { Management Department }\end{array}$} & $\begin{array}{l}\text { Correct relations between individual subdivisions, which is associated with the definition of their purpose, } \\
\text { working conditions, and incentives; division of responsibility between employees; organization of information } \\
\text { flows; the choice of appropriate technical means }\end{array}$ \\
\hline & Clear definition of competencies, impossibility to duplicate authority of management \\
\hline Clear subordination \\
\cline { 2 - 3 } Clear definition of decision-maker \\
\cline { 2 - 3 } & $\begin{array}{l}\text { Responsibility for mistakes and errors } \\
\text { Correspondence of rights and duties }\end{array}$ \\
\hline $\begin{array}{l}\text { Influence of professional skills and abilities on the operating results of the enterprise but not the influence of the } \\
\text { human factor }\end{array}$ \\
\hline $\begin{array}{l}\text { A change in the working conditions of one subdivision must be agreed in order not to lead to a new functional, } \\
\text { legal or other correlation of employees and subdivisions (a change in the ideal structure) }\end{array}$ \\
\hline Increase in the responsibility of higher units in the structure \\
\hline
\end{tabular}

Source: developed by the author

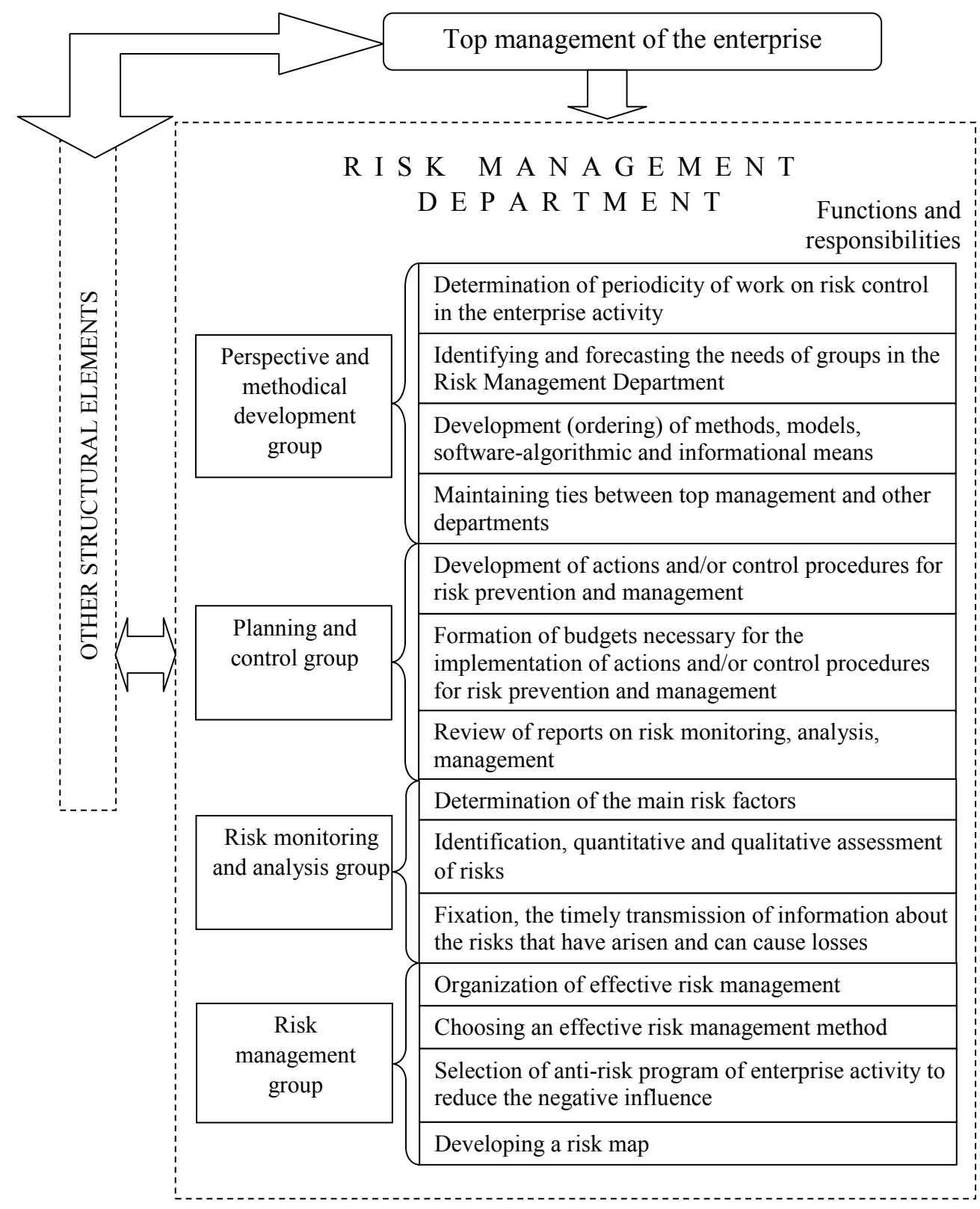

Figure 7. Organization of work of the Risk Management Department

Source: developed by the author 
top management, and Risk Management Department, each of which has its own specifics of activities and a list of authorities.

The very organization of work and functions of each group of the Risk Management Department is shown in Figure 7.

In the Risk Management Department, it is worth to form four groups, each team must clearly perform its tasks, know its functions and responsibilities. A prerequisite for the effective operation of the Risk Management Department is to take into account the time aspect of risk, namely, the time dependence of the level of uncertainty in the activity (Figure 5); therefore, it is necessary to make decisions in the zone of low and moderate level of risk.

The enterprise's top management occupies the leading role in making managerial decisions related to the issues of risk management since the very top management approves decisions in relation to the implementation of effective risk management plan, the introduction of an anti-risk program of action, or rejects if considers them meaningless.

\section{Conclusions}

Therefore, for the management of a production enterprise in the current conditions of a market economy, effective use of technical, economic, organizational, informational, financial, labour, and other resources is necessary. At the same time, the management system and its various levels play an important role in increasing the competitiveness and profitability of the enterprise, where, regardless of the form of ownership and professional orientation, an organizational structure of management is formed that ensures efficient activity.

\section{References:}

Alieksieiev, I. V., Bondarchuk, M. K., Voloshyn, O. P. (2016). Rozroblennja klasyfikatora elementarnykh cykliv upravlinnja v umovakh sanaciji dlja riznykh struktur pidpryjemnycjkogho biznesu [Development of a classifier of elementary control cycles under remediation conditions for different business enterprise structures]. Upravlinsjka, finansova ta marketynghova dijaljnistj pidpryjemstv $v$ umovakh nestijkoji ekonomiky: kolektyvna monoghrafija [Management, financial and marketing activity of enterprises in conditions of unstable economy: collective monograph]. Dnipropetrovsjk: Poroghy.

Bazylevych, P. R. (2011). Formuvannja asynkhronnykh dyskretnykh system biznes-procesiv pidpryjemstv [Formation of asynchronous discrete systems of business processes of enterprises] (PhD Thesis), Lviv: National university «Lviv polytechnika».

Vendrov, A. M. (2004). Metody i sredstva modelirovaniya biznes-protsessov (obzor) [Methods and simulars of business processes (review) ]. Moscow: DZhET INFO Publishing. (in Russian). Retrieved from: http://www.jetinfo.ru/ Sites/new/Uploads/2004_10.7BBAD6EFC6554E8791CCBF730A438BA8.pdf (accessed 27 January 2019).

Vyshnevetskyi, V. I., Hryshuk, H. P., Vyshnevetskyi, V.V. (2006). Modeli «zolotogho peretynu» i loghista rozvytku pidpryjemstv malogho i serednjogho biznesu [Models of the «golden section» and the logist of development of enterprises of small and average business]. System management techniques, technology and organization of production, repair and operation of cars: a collection of scientific works, 11, 275-278.

Volkova, V. N., Denisov, A. A. (2001). Osnovy teorii sistem i sistemnogo analiza: uchebnik dlya studentov vuzov [Bases of the theory of systems and system analysis: the textbook for students of higher education institutions]. St. Petersburg: SPbGTU. (in Russian)

Harashchuk, O. V., Matijenko, V. D., Celina, N. O. (2009). Kilikisna ocinka investycijnykh ryzykiv [Quantitative assessment of investment risks]. Visnyk ekonomichnoji nauky Ukrajiny [Herald of of Economic Science of Ukraine], 1(15), 55-57. Retrieved from: http://dspace.nbuv.gov.ua/bitstream/handle/123456789/8299/13-Garaschuk. pdf? sequence $=1$ (accessed 27 January 2019).

Hronska, N. S. (2006). Osnovy teoriji gharmonijnykh peretvorenj v ekonomici: monoghrafija [Fundamentals of the theory of harmonious transformations in economics: monograph]. Lviv: Kraj. (in Ukrainian)

Dezhkina, I. P. (2008). Upravlenie promyshlennym predpriyatiem na osnove printsipa «zolotogo secheniya» [Management of the industrial enterprise on the basis of the principle of «golden ratio»]. Herald of Voronezh State University. Series: Economy and management, 2, 8-12.

Ivanus, O. I. (2011). Garmonichnyy innovatsionnyy menedzhment: monografiya [Harmonious innovative management: monograph]. Moscow: Librokom. (in Russian)

Ivanus, O. I. (2006). Zolotoe sechenie v sistemakh s binomialnym zakonom raspredeleniya [Golden ratio in systems with the binomial law of distribution]. Akademiya Trinitarizma [Trinitarizma academy]. Retrieved from: http://www.trinitas.ru/rus/doc/0232/009a/02321028.htm (accessed 27 January 2019).

Ivanus, O. I. (2005). Kod da Vinchi v biznese, ili Garmonichnyy menedzhment po Fibonachchi [The Da Vinci Code in business, or Harmonious management according to Fibonacci]. Moscow: Lenand. (in Russian)

Ivanus, O. I. (2003). Metodika ispolzovaniya «zolotogo secheniya» v modeli garmonichnogo rynka [Technique of use of "golden ratio" in model of the harmonious market]. Problems of harmony, symmetry and golden intersection in nature, science and art: a collection of scientific works, 15, 291-296.

Ivanus, O. I., Mironova, N. A. (2008). O samogarmonizatsii finansovo-ekonomicheskikh pokazateley dinamichno razvivayushchikhsya kompaniy [About self-harmonization of financial and economic indicators of dynamically 
developing companies]. Akademiya Trinitarizma [Trinitarizma academy]. Retrieved from: http://www.trinitas.ru/ rus/doc/0230/003a/02301059.htm (accessed 27 January 2019).

Ivanchuk, S. I. (2008). Aspekty zvjazku «zolotogho peretynu» z zhyttjevym cyklom rozvytku ekonomichnoji systemy [Aspects of communication «golden section» with the life cycle of economic system development]. Scientific and technical collection «Herald of the National Transport University», 17, 47-51.

Ihnatieva, I. A. (2008). Innovacijni pidkhody adaptaciji orghanizacijnykh struktur upravlinnja pidpryjemstv do pryncypiv korporatyvnogho upravlinnja [Innovative approaches to the adaptation of organizational structures of enterprise management to the principles of corporate governance]. Herald of Khmelnytskyi national university. Economic Sciences series, 2(3), 108-111.

Kaliuzhna, N. Gh. (2005). Udoskonalennja orghanizacijnoji struktury upravlinnja mashynobudivnogho pidpryjemstva [Improvement of the organizational structure of the management of the machine-building enterprise]. (PhD Thesis), Lughansjk: East Ukrainian National University named after Volodymyr Dahl.

Klymenko, S. Je. (2011). Mekhanizmy restrukturyzaciji mashynobudivnogho pidpryjemstva $\mathrm{z}$ urakhuvannjam analizu rynku [Mechanisms of restructuring of machine-building enterprise taking into account market analysis]. (PhD Thesis). Zaporizhzhja: Classical Private University.

Korzachenko, O. V. (2015). Modeljuvannja biznes-procesiv pidpryjemstv: metodologhiji, pidkhody ta metody [Modeling business processes of enterprises: methodologies, approaches and methods]. Scientific Herald of Kherson State University. Economic Sciences series, 1(11), 171-175.

Kriuchkova, I. V. (2008). Strukturirovanie ekonomiki: deystvie Zakona zolotogo secheniya [Structuring economy: operation of the Law of golden ratio]. Institute of evolutionary economy. Retrieved from: http://iee.org.ua/ru/pub/ p101 (accessed 27 January 2019).

Kriuchkova, I. V. (2004). Strukturni chynnyky rozvytku ekonomiky Ukrajiny [Structural factors of economic development of Ukraine]. Kyiv: Naukova dumka. (in Ukrainian)

Markovskyi, O. V. (2010). Modeljuvannja struktury ta upravlinnja ryzykamy v dijaljnosti komercijnogho banku [Modeling the structure and risk management in the activities of the commercial bank]. (PhD Thesis), Zaporizhzhja: Classical Private University.

Becker, J., Vylkov, L., Taratukhyn, V., Kugeler, M., Rosemann, M. (2007). Menedzhment processov [Management of processes]. Moscow: Eksmo. (in Russian)

Metelenko, N. Gh. (2009). Formuvannja orghanizacijnoji struktury upravlinnja jak skladovoji vnutrishnjogho ghospodarsjkogho mekhanizmu promyslovogho pidpryjemstva [Formation of the organizational structure of management as a component of the internal economic mechanism of an industrial enterprise]. Investments: practice and experience, 10, 46-49.

Petrenko, S.A. (2010). Porivnjaljnyj analiz modelej orghanizacijnykh struktur pidpryjemstva [Comparative analysis of models of organizational structures of the enterprise]. Collection of scientific works «Bulletin of the International Nobel Economic Forum», vol. 2, no. 1(3), 245-252.

Pysarevskyi, I. M., Mokhrina, L. A., Poznjakova, O. V. (2008). Menedzhment orghanizacij [Management of organizations]. Kharkiv: KhNAMGH. (in Ukrainian)

Prodius, I. P., Pristupa, M. P. (2012). Udoskonalennja orghanizacijnoji struktury upravlinnja promyslovogho pidpryjemstva [Improvement of the organizational structure of the management of an industrial enterprise]. Ekonomika: realiji chasu : naukovyj zhurnal [ECONOMICS: time realities], 3-4, 17-22. Retrieved from: https://economics.opu.ua/files/archive/2012/No3-4/17-22.pdf (accessed 27 January 2019).

Radiuk, M. S. (2003). Samorazvitiya sistem i zolotoe sechenie [Self-development of systems and golden ratio]. Problems of harmony, symmetry and golden intersection in nature, science and art: a collection of scientific works, 15, 61-68. Repin, V., Elyferov, V. (2013). Protsessnyy podkhod k upravleniyu. Modelirovanie biznes-protsessov [Process approach to management. Modeling of business processes]. Moscow: Mann, Ivanov i Ferber. (in Russian)

Sedikova, I. O. (2013). Vydy orghanizacijnykh struktur upravlinnja sluzhby marketynghu na pidpryjemstvi sokovoji ghaluzi [Types of organizational structures of marketing management at the juice industry]. Food Industry Economics, 4(20), $21-26$.

Simakov, K. I. (2001). Zabezpechennja efektyvnosti orghanizacijnoji struktury upravlinnja promyslovogho pidpryjemstva [Ensuring the effectiveness of the organizational structure of the management of an industrial enterprise] (PhD Thesis). Donecjk: Institute of Industrial Economics, National Academy of Sciences of Ukraine.

Soroko, E. M. (2006). Zolotye secheniya, protsessy samoorganizatsii i evolyutsii sistem: vvedenie v obshchuyu teoriyu garmonii sistem [Golden ratios, processes of self-organization and evolution of systems: introduction to the general theory of harmony of systems]. Moscow: URSS. (in Russian)

Soroko, E. M. (2003). Ustoychivye neravnovesnye sostoyaniya samoorganizuyushchikhsya sistem: obobshchennye zolotye secheniya i sootnosheniya razmernostey [Steady nonequilibrium conditions of self-organizing systems: the generalized golden ratios and ratios of dimensions]. Problems of harmony, symmetry and golden intersection in nature, science and art: a collection of scientific works, 15, 43-50.

Bilotserkivets, O. Gh., Burlai, T. V., Honchar, N. Ju. (2007). Strukturna gharmonizacija ekonomiky jak chynnyk ekonomichnogho zrostannja [Structural harmonization of the economy as a factor of economic growth]. Kyiv: Ekspres. (in Ukrainian)

Fox, M. S., Gruninger, M. (1998). Enterprise Modeling. American Association for Artificial Intelligence. AI Magazine, $3,109-121$. 